Pratika Ayuningtyas, Tell : Teaching of English Language and Literature

Vol. 8, No. 1, 7 - 18 Doi: http://dx.doi.org/10.30651/tell.v8i1.4327

\title{
An Exploration of Anxiety towards English for Specific Purposes (ESP)
}

\author{
Pratika Ayuningtyas* \\ Politeknik Sawunggalih Aji, Indonesia \\ pratika.ayuningtyas@gmail.com \\ *corresponding author
}

\author{
Article History \\ Received: 17 February 2020 \\ Reviewed: 11 March 2020 \\ Accepted: 03 April 2020 \\ Published: 30 April 2020 \\ Highlights \\ - Students suffered from \\ average to high level of \\ anxiety. \\ - Communication \\ Apprehension is the highest \\ anxiety factor.
}

\begin{abstract}
This study aims at exploring the Foreign Language Anxiety among the ESP Students. The participants in this study were 183 students of three different departments of Politeknik Sawunggalih Aji, Indonesia. There were 56 students of Information Technology Department, 93 students of Accounting Department and 34 students of Business Administration Department. The Foreign Language Anxiety Scale (FLCAS) (Horwitz, Howitz \& Cope, 1986) was used to collect the data. The general level of anxiety among students of Politeknik Sawunggalih Aji, Indonesia is average to high as their mean score is 81.84 . There are 169 students who suffered from average to high anxiety or $92.34 \%$. The results of the analysis revealed that the students of Information Technology department experienced the highest level of anxiety with the mean score of 84.8; the students of Accounting department experienced the next higher level of anxiety with the mean score of 80,8 and the students of Business Administration department experienced the lowest of anxiety with the mean score of $79,8 \%$. Knowing these results, teachers should provide the materials and the teaching method which can help students overcoming their anxiety towards English. Therefore the level of anxiety can be pressed to low.
\end{abstract}

Keywords: FLA, Anxiety, ESP.

\section{Introduction}

Data from the English First English Proficiency Index showed that Indonesia ranked 61th out of 100 countries with the score of 50.06 based on the research conducted by the International English Education Company English First (EF) (EF, 2019). The number showed that Indonesia is considered low in English proficiency. Therefore, to overcome the problem teachers should understand the students' problem. Research done by Tridinanti (Tridinanti, 2018) showed result of early observation that some students feel uncomfortable in speaking English in front of the class. Due to lack of preparation, some students also felt less confident in speaking English. The students are afraid of making mistakes; they cannot speak English well. The problem in English proficiency in Indonesia is not only happen in English Language Education department, but also the education in general.

Vocational higher education has a specific goal which is to create its graduates become professionals and skilful persons to meet the need of the related industry. The core of vocational education includes five categories: curriculum, instruction and delivery options, student assessment, clientele, and program evaluation (accountability) (Rojewski, 2002). The curriculum especially, is to reflect the circumstances in the field which are considered important and are happening (Safitri \& Suciati, 2018). The surrounding of curriculum has changed from the exact 
academic set to academic or general competence, technical and job-specific skills, interpersonal skills and behavioral traits (Rojewski 2009 cited in Safitri \& Suciati, 2018).

English is one of the major competence of Politeknik Sawunggalih Aji, Indonesia which is required to obtain. As one of the skills that students should master in vocational higher education, English is materialized in the form of English for Specific Purposes. English for Specific Purposes (ESP) is designed to build up students' skill in order to enable them to communicate in English (Tarnopolsky 2009 as cited in Baghban \& Zohoorian, 2011). In Politeknik Sawunggalih Aji, ESP is taught based on each department specialization. Therefore, each department got English subject as degree requirement.

Performing English has been a massive issue among the students of ESP classes in Politeknik Sawunggalih Aji for half a decade. Performing English here such as writing and speaking are the major problems students face. In ESP class usually students are silent when the teacher starts the discussion. Sometimes they answer teacher's questions in hesitant or in a whisper. They seems to be anxious whenever the teacher asks them to answer, to present or to share opinions. These signs of anxiety could lead to inconducive situation to learn English. As (Ahmed, 2016) said that speaking anxiety can have a negative repercussion on EFL learners because it can lead them to the negative self assessment, mental block and poor performance. The impact to all the high anxiety level is the lack of improvement of their English. Although some students were confidence enough to speak, however communicative competence is not sufficient for learners to improve their speaking skill. Without positive attitudes towards the speaking performance, the aim of speaking will not be obtainable for learners (Bekai \& Harkouss, 2018). Therefore, the teacher should be able to choose the appropriate strategies and the materials so it can help the students to communicate using more English.

The investigation of English for Specific Purposes (ESP) students' affective factors involved in EFL is particularly relevance (Amengual-Pizarro, 2018). Therefore this research aims to explore the role of Foreign Language Anxiety that experienced by ESP Students in Politeknik Sawunggalih Aji. More specificcaly, the research are aimed to answer the following questions:

(1) What level of FLA do students of Politeknik Sawunggalih Aji have towards the English learning?

(2) What is the main souce of their anxiety?

(3) How the degree of FLA differs from one department to other?

\section{Method}

\section{Participants}

The participants of this research were the first to third year students of Politeknik Sawunggalih Aji. There are total 183 students of three departments. The distributions are as follow: 93 students of Accounting Department; 34 students of Business Administration Department; and 56 students of Information Technology Department.

As regards the year of study, 26\% (47 students) were from the first year, $48 \%$ (88 students) were from the second year and $27 \%$ (49 students) were from the third year. All the participants got 
Pratika Ayuningtyas, Tell : Teaching of English Language and Literature Vol. 8, No. 1, 7 - 18 Doi: http://dx.doi.org/10.30651/tell.v8i1.4327

English Subject for at least two semesters (Information Technology Department), while the other two departments got English subject for two years or four semesters.

\section{Instruments and Data Collection}

The instrument used in this study was the Foreign Language Classroom Anxiety Anxiety Scale (FLCAS) by (HORWITZ et al., 1986). It consisted of 33 items which were translated into Bahasa to help students get the meaning precisely. The questionnaire was in the Google form which the link was sent to each students using Whatsapp Group. To solve any possible problem happened during the completion, the administrator stayed in the classroom. The 33 items are rated using 4point Likert scale rather than 5-point Likert scale. The research used 4-point Likert scale to make students commit to their answer rather than choosing the average number. It was also proven by Mak (Mak, 2011) that using 4-point scale resulted high level of internal reliability.

The questionnaire items were completed after during the class period when the regular class finished around October to December 2019. It took about 15 to 20 minutes to complete the questionnaire.

\section{Data Analysis}

The 33 items from FLCAS purposes to score three types of foreign language anxiety, which are: communication apprehension (item number 1, 4, 8, 13, 14, 18, 23, 26, 28, 29 and 31), test anxiety (item number 3, 5, 7, 9, 10, 11, 15, 16, 19, 20, 21, 24, 25, 27 and 33), and negative evaluation (item number 2, 6, 12, 17, 22, 30 and 32). Total scores of the scale range from the lowest 33 to the highest 132. The low score represents a low level of anxiety, the high score represents high level of anxiety. The limit for mean score for each question is 2.5; and the mean score for the total score is 82.5.

The results of the questionnaire were analyzed using the Statistical package for the Social Sciences (SPSS) 20.0. Each department was grouped. Then the result was analyzed based on the three types of foreign language anxiety (communication apprehension, test anxiety, and negative evaluation). Each group's mean score for each type of foreign language anxiety were analyzed to count the lowest mean score and the highest score which represent their level of anxiety. Each group for each question was also analyzed to get the lowest and the highest factor of anxiety.

\section{Result and Discussion}

\section{The Level of Students' FLA towards the English Learning}

To get the result of the level of students FLA, the total scores of all students were calculated. The total score went from 48 to 118. According to Guillen (2012) as cited in (Amengual-Pizarro, 2018), the participants were classified into three different level of anxiety: Low, Average and High. In this study, the low level of anxiety was from 33 to 65 . Those who scored 66 to 98 were identified has average level of anxiety. The high level of anxiety scored 99 to 132.

The descriptive statistics showed that there were 14 students $(7,65 \%)$ who identified as low anxiety level students. The 149 students $(81 \%)$ suffered from the average anxiety level. The 20 students (11\%) were identified as high anxiety level. Therefore, $92 \%$ of the students were suffered from average to high anxiety. The mean score for the 183 students was 81,84 and the standard deviation was 12,50 . 
Pratika Ayuningtyas, Tell : Teaching of English Language and Literature

Vol. 8, No. 1, 7 - 18 Doi: http://dx.doi.org/10.30651/tell.v8i1.4327

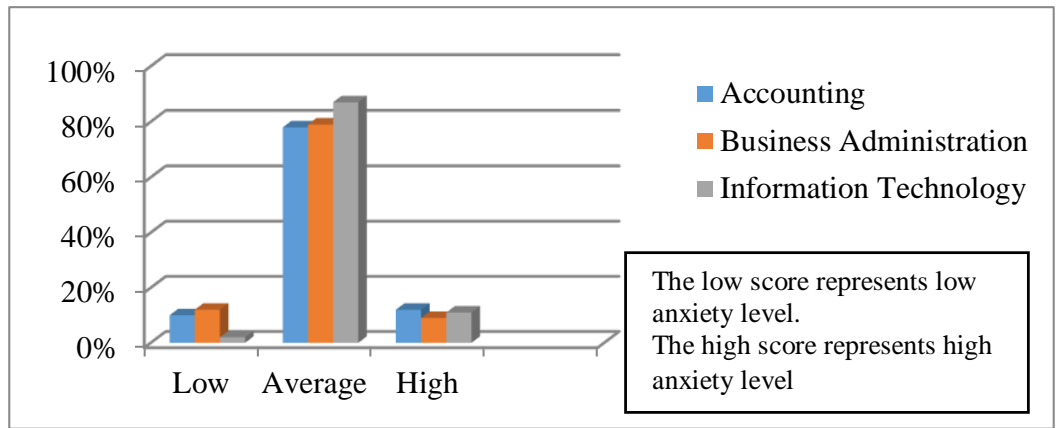

Figure 1. Students' FLA Level based on group

Based on group, the description for each department is as follow. Accounting department $(\mathrm{N}=93)$ has the mean score of 80.8 with the standard deviation 12.498 . The figure 1 above shows that Accounting department has higher number of students who suffered from high anxiety with 11 students (12\%). The department has 73 students (78\%) identified as average level of anxiety, and only 9 students $(10 \%)$ who has low anxiety level.

For Business Aministration department $(\mathrm{N}=34)$, it has the mean score of 79.8 with the standard deviation 12.484. The mean score is lower than the questionnaire mean of 82.5 , it means that the department has lower anxiety level than any other departent. The department has 4 students (12\%) who has low anixety level, 27 students (79\%) who identified as averagely anxious, and 3 students (9\%) who suffered from high anxiety level. It can be concluded that Business Administration students were the least anxious.

The Information Technology department $(\mathrm{N}=56)$ has the mean score of 84.8 which are higher than the mean of questionnaire 82.5. It means than Information Technology setudents has serious problem with anxiety. There were 49 students (87\%) who has average anxiety, and 6 students (11\%) who suffered from high anxiety. Furthermore, there was only one (2\%) student who has low anxiety. It means that Information Technology was the most anxious department related to English learning.

\section{The Main Source of FLA among ESP Students}

The three types of performance anxiety were analyzed each types to get the mean score and the standard deviation. The data are shown in ascending order to facilitate comprehension. The highest score shows high level of FLA. The three types of performance were communication apprehension, negative evaluation and test anxiety. 
Pratika Ayuningtyas, Tell : Teaching of English Language and Literature

Vol. 8, No. 1, 7 - 18 Doi: http://dx.doi.org/10.30651/tell.v8i1.4327

Table 1

Students' level of Communication Apprehension

\begin{tabular}{llll}
\hline & $\mathbf{N}$ & Mean & Std. Deviation \\
\hline Q18 & 183 & 2.38 & .905 \\
Q1 & 183 & 2.44 & .941 \\
Q14 & 183 & 2.46 & .998 \\
Q26 & 183 & 2.46 & .936 \\
Q4 & 183 & 2.48 & 1.073 \\
Q23 & 182 & 2.51 & .945 \\
Q13 & 183 & 2.52 & .851 \\
Q29 & 183 & 2.59 & .979 \\
Q31 & 183 & 2.66 & .802 \\
Q28 & 183 & 2.80 & .874 \\
Q8 & 183 & 2.82 & .975 \\
\hline
\end{tabular}

There are six items which are higher than the mean score of 2.50 , therefore Communication Apprehension placed first as the source of students FLA. The mean score for communication apprehension is 2.56. As seen in Table 1, the main source of the students' FLA of communication apprehension was from Q8: I start to panic when I have to speak without preparation in the English class. It is clearly seen that the students' speaking anxiety is high. The result is in line with Mak (2011 as cited by Ahmed, 2016) that speaking anxiety is the most influential factors of students' negative performance and students' ability to process information. Another consistent result was a lack preparation in advance results in students' low self esteem and less talk in the classroom (Ahmed, 2016).

The second type of performance anxiety is test anxiety. Test anxiety placed second as the source of students' FLA. The mean score for Test Anxiety is 2.46. The highest score was from Q9 : I worry about the consequences of failing in my English Class. It can be said that students concerned about their score of English subject. They were anxious about their performance which can affect their score in English. The result is consistent with Vo et al (Vo et al., 2017) that students with high levels of anxiety usually get lower achievement. It can be seen from the Table 2 below that the least influential factor of test anxiety was Q16 (I often feel like not going to my English class). It can be concluded that students' passion for English class was high that they did not have any thoughts of skipping the class.

Table 2.

Students' level of Test Anxiety

\begin{tabular}{llll}
\hline & $\mathbf{N}$ & Mean & Std. Deviation \\
\hline Q17 & 183 & 1.81 & .937 \\
Q12 & 183 & 1.91 & .928 \\
Q30 & 183 & 2.40 & .983 \\
Q2 & 183 & 2.71 & 1.063 \\
Q32 & 183 & 2.74 & .930 \\
Q6 & 183 & 2.80 & .965 \\
Q22 & 183 & 2.85 & .931 \\
\hline
\end{tabular}


The third influential factor of students' FLA is Negative Evaluation. Negative Evaluation has mean score of 2.43 with the highest anxiety stands for Q22 (I always feel that the other students speak English better than I do). From the result, it is seen that students has low confidence in speaking. This was consistent with Bhati's research result (Studies et al., 2016) that in English communication-based classroom, students are more anxious as compares to the other. The result is was also in line with Tridinanti's (Tridinanti, 2018) that self-confidence is the influential factor of speaking achievement. Therefore, the low self-confidence the low speaking achievement ones get. Students who have low confidence usually get lower achievement. While the lowest anxiety factor of negative evaluation was Q17 (I'm afraid that my language teacher is ready to correct every mistake I make). This can be concluded that the classroom is communicative that there was no gap between the teacher and the students in regard of classroom ambience. The result can be seen from the Table 3 below.

Table 3.

Students' level of Negative Evaluation

\begin{tabular}{llll}
\hline & $\mathbf{N}$ & Mean & Std Deviation \\
\hline Q16 & 183 & 1.43 & .744 \\
Q20 & 183 & 2.01 & .929 \\
Q5 & 183 & 2.02 & .920 \\
Q25 & 183 & 2.22 & .937 \\
Q3 & 183 & 2.27 & .984 \\
Q10 & 183 & 2.42 & 1.023 \\
Q21 & 183 & 2.44 & .947 \\
Q19 & 183 & 2.56 & .992 \\
Q15 & 183 & 2.58 & .939 \\
Q7 & 183 & 2.58 & .990 \\
Q11 & 183 & 2.67 & .934 \\
Q27 & 183 & 2.67 & .885 \\
Q24 & 183 & 2.73 & .931 \\
Q33 & 183 & 2.90 & 1.001 \\
Q9 & 183 & 3.01 & 1.014 \\
\hline
\end{tabular}

\section{The Descriptive Results of FLA Based on Groups}

For deeper understanding on students' responses, the descriptive statistic should be stated explicitly. The reason three groups are being analyzed separately is because there is an assumption of difference anxiety levels of each group. The assumption was there because the three groups have different number of English subject.

Accounting has four English subjects which are from the first semester to fourth, those subjects have both theoretical and practical material with theoretical has more duration than practical. Business Administration has four English subjects which are from the first semester to fourth, those subjects have both theoretical and practical material with practical class has more duration than theoretical one. While for information Technology Department has the least English subject. It has only two subjects for the first and second semester, those subjects have both theoretical and practical material with less practical class. 
The mean score for Accounting Department is 2.45 indicating the department are less anxious due to the mean score for the questionnaire is 2.5. The highest mean score is Q9 (I start to panic when I have to speak without preparation in the English class) which means that their speaking anxiety is high. Meanwhile, the least score is Q16 (I often like not going to my English class). It means that students were passionate about the English class and did not want to skip the subject.

For Business Administration Department, the mean score is 2.41. It slightly has less anxiety than Accounting Department. The highest mean score is Q27 (When I'm on my way to English Class, I feel very sure and relaxed). This item is reversely coded, therefore the students agreed most on this item because they are sure and relaxed. It means the class did not make the students anxious. While the lowest mean is Q16 (I often like not going to my English class). As Accounting Department did, the Business Administration department also has less anxiety when they come to their English class.

These two departments are much exposed to English than Information Technology department. Therefore, these departments show less anxiety level as it said by Al-zoubi (Al-zoubi, 2019) that students who expose to English more are significantly able to develop the four skills of English. Moreover, Al-zoubi (Al-zoubi, 2019) points out that there is a strong impact of exposure to English language on language acquisition.

The Information Technology department has the highest mean score of 2.65, indicating that the department is the most anxious than the other department. The descriptive results are in line with the research result done by Souriyavongsa (Souriyavongsa et al., 2013) that one factor of why students are poor in English proficiency is that there is lack of English foundation background. The Information Technology Department has the least background of English classes, therefore it shows that the students of the department has the highest anxiety. It has higher score than the mean score of 2.5. The highest mean score is Q8 (I start to panic when I have to speak without preparation in the English class), means that the students has high anxiety towards speaking session. Moreover, students' confidence is also low that they start panicking when they have to speak without preparation. The lowest mean score is Q16 (I often like not going to my English class). The department has the same item on the lowest mean score. It means that they are less anxious when they have English class on their schedule.

The Table 4 below shows the mean score and the standard deviation based on groups for each item. 
Pratika Ayuningtyas, Tell : Teaching of English Language and Literature Vol. 8, No. 1, 7 - 18 Doi: http://dx.doi.org/10.30651/tell.v8i1.4327

Table 4

Descriptive analysis of FLA based on group

\begin{tabular}{lllllll}
\hline & \multicolumn{2}{l}{ Accounting } & \multicolumn{2}{l}{ Business Adm } & \multicolumn{2}{l}{ Inform Tech } \\
Question & $\mathbf{N = 9 3}$ & & $\mathbf{N = 3 4}$ & & $\mathbf{N}=\mathbf{5 6}$ & \\
\cline { 2 - 7 } & $\mathbf{M}$ & SD & M & SD & M & SD \\
\hline Q1 & 2.40 & .957 & 2.15 & .989 & 2.70 & .829 \\
Q2 & 2.77 & 1.095 & 2.85 & 1.048 & 2.52 & 1.009 \\
Q3 & 2.17 & .985 & 2.24 & .987 & 2.46 & .972 \\
Q4 & 2.39 & 1.104 & 2.38 & 1.074 & 2.70 & 1.008 \\
Q5 & 1.90 & .910 & 1.85 & .784 & 2.32 & .956 \\
Q6 & 2.80 & .962 & 2.71 & 1.001 & 2.86 & .962 \\
Q7 & 2.57 & 1.015 & 2.74 & .931 & 2.52 & .991 \\
Q8 & 2.75 & .985 & 2.65 & 1.012 & $\mathbf{3 . 0 4}$ & .914 \\
Q9 & $\mathbf{3 . 1 8}$ & .999 & 2.62 & 1.045 & 2.95 & .961 \\
Q10 & 2.26 & 1.052 & 2.32 & .945 & 2.73 & .963 \\
Q11 & 2.57 & .971 & 2.76 & .855 & 2.77 & .914 \\
Q12 & 1.77 & .957 & 1.79 & .914 & 2.21 & .825 \\
Q13 & 2.52 & .916 & 2.65 & .734 & 2.45 & .807 \\
Q14 & 2.40 & 1.012 & 2.38 & 1.074 & 2.61 & .928 \\
Q15 & 2.49 & .996 & 2.62 & 1.015 & 2.70 & .784 \\
Q16 & $\mathbf{1 . 4 0}$ & .768 & $\mathbf{1 . 2 9}$ & .676 & $\mathbf{1 . 5 5}$ & .737 \\
Q17 & 1.77 & .968 & 1.74 & 1.053 & 1.93 & .806 \\
Q18 & 2.53 & .892 & 2.44 & .960 & 2.09 & .837 \\
Q19 & 2.52 & .996 & 2.41 & 1.076 & 2.73 & .924 \\
Q20 & 1.99 & .961 & 1.76 & .819 & 2.18 & .917 \\
Q21 & 2.52 & 1.017 & 2.29 & .938 & 2.41 & .826 \\
Q22 & 2.82 & .955 & 3.06 & .851 & 2.77 & .934 \\
Q23 & 2.45 & .930 & 2.29 & 1.031 & 2.75 & .879 \\
Q24 & 2.73 & .899 & 2.71 & .970 & 2.75 & .977 \\
Q25 & 2.18 & .966 & 2.21 & 1.038 & 2.30 & .829 \\
Q26 & 2.43 & .925 & 2.15 & 1.019 & 2.71 & .847 \\
Q27 & 2.65 & .917 & $\mathbf{3 . 0 6}$ & .851 & 2.46 & .785 \\
Q28 & 2.78 & .907 & 2.65 & .917 & 2.93 & .783 \\
Q29 & 2.55 & .984 & 2.41 & 1.048 & 2.77 & .914 \\
Q30 & 2.26 & .988 & 2.38 & 1.129 & 2.64 & .841 \\
Q31 & 2.60 & .823 & 2.65 & .849 & 2.77 & .738 \\
Q32 & 2.69 & .989 & 2.68 & 1.007 & 2.86 & .773 \\
Q33 & 3.02 & 1.011 & 2.94 & .952 & 2.68 & .993 \\
\hline & & & & & &
\end{tabular}

\section{Conclusion}

Based on the research result, the students suffer from average to high anxiety. In the meantime, teacher should be able adapt methods of teaching and learning which can bridge the students to the material. In addition, teachers should be able to adapt the material for students to experience the real world (English communication) as much as possible. The institution also should be able to create a curriculum which is able to cover the need of the industry as well as improve students' competence in related field. Moreover, the result gives two more questions which can be other explorations for the next research. The first is factors influencing students' language anxiety, the second is what teachers can do for overcome the students' anxiety. 
Pratika Ayuningtyas, Tell : Teaching of English Language and Literature

Vol. 8, No. 1, 7 - 18 Doi: http://dx.doi.org/10.30651/tell.v8i1.4327

\section{References:}

Abdala, A., \& Elnadeef, E. (2019). English Language Anxiety and Stress among Saudi Students in the First Year at College of Sciences and Arts in Dharan Aljanoob. Online Submission, 2(1), 270-275.

Ahmed, N. (2016). An Exploration of Speakimg Axienty with Kurdish University EFL Learners. Vol.7, No.(Speaking anxiety), 99-106.

Akkakoson, S. (2016). Speaking Anxiety in English. Malaysian Journal Of Learning and Instruction, 13, 63-82.

Al-zoubi, S. M. (2019). The Impact of Exposure to English Language on Language Acquisition The Impact of Exposure to English Language on Language Acquisition. Jounal of Applied Linguistics and Language Research, 5(4), 151-162.

Amengual-Pizarro, M. (2018). Foreign language classroom anxiety among English for Specific Purposes (ESP) students. International Journal of English Studies, 18(2), 145-159.

Awada, G., \& Diab, H. (2018). The Effect of Google Earth and Wiki Models on Oral Presentation Skills of University EFL Learners. International Journal of Teaching and Learning in Higher Education, 30(1), 36-46.

Balla, A. (2017). Foreign Language Anxiety in Saudi Classroom: A Case Study of Saudi Tertiary Female Students in Prince Sattam University. English Language Teaching, 10(5), 28.

Choi, N., No, B., Jung, S., \& Lee, S. (2019). What affects middle school students' english anxiety in the efl context? Evidence from south korea. Education Sciences, 9(1).

Dewaele, J.-M., \& Al-Saraj, T. (2013). Foreign language anxiety: Some conceptual and methodological issues. Impuls, 68(3), 72-78.

Djumingin, S., Weda, S., \& Juanda. (2019). Anxiety in classroom presentation in teaching Learning interaction in english for students of indonesian study program at higher education. International Journal of Education and Practice, 7(1), 1-9.

$\begin{array}{lllll}\text { EF. } & \text { (2019). } & \text { Ef } & 2019 . & 52 .\end{array}$ www.ef.com/epiwww.ef.com/epiwww.efset.org\%0Awww.ef.com/epi\%0Awww.ef.com/epi www.ef.com/epiwww.efset.org\%0Awww.ef.com/epi

Gerencheal, B., \& Mishra, D. (2019). Foreign language anxiety among ethiopian university EFL students. International Journal of Innovative Technology and Exploring Engineering, $8(7 \mathrm{C}), 43-48$.

Hashemi, M. (2011). Language stress and anxiety among the English language learners. Procedia - Social and Behavioral Sciences, 30, pp. 1811-1816. 
Pratika Ayuningtyas, Tell : Teaching of English Language and Literature Vol. 8, No. 1, 7 - 18 Doi: http://dx.doi.org/10.30651/tell.v8i1.4327

HORWITZ, E., HORWITZ, M., \& COPE, J. (1986, 6). Foreign Language Classroom Anxiety. The Modern Language Journal, 70(2), 125-132.

Mede, E. (2017). The Predictor Roles of Speaking Anxiety and English Self Efficacy on Foreign Language Speaking Anxiety. Journal of Teacher Education and Educators, 6(1), 117-131.

Murugaiah, P. (2016). Pecha Kucha style powerpoint presentation: An innovative call approach to developing oral presentation skills of tertiary students. Teaching English with Technology, 16(1), 88-104.

Nasreen Bhati, Shumaila Memon, H. P. (2016). Investigating the Perceptions of Pakistani English Language Learners on Language Learning Anxiety in EFL Classroom. Advances in Language and Literary Studies, 7(5). https://doi.org/10.7575/aiac.alls.v.7n.5p.23

Nejad, A., \& Mahfoodh, O. (2019). Assessment of oral presentations: Effectiveness of self-, peer, and teacher assessments. International Journal of Instruction, 12(3), 615-632.

Papadima-Sophocleous, S., Kakoulli Constantinou, E., Giannikas, C., \& Zareva, A. (2019). Providing feedback on the lexical use of ESP students' academic presentations: teacher training considerations. ESP teaching and teacher education: current theories and practices(2019), 63-78.

Samoilova, V., Thanh, V., \& Wilang, J. (2017). Anxiety among Engineering Students in a Graduate EFL Classroom. Online Submission.

Santos, A., Cenoz, J., \& Gorter, D. (2018). Attitudes and anxieties of business and education students towards English: some data from the Basque Country. Language, Culture and Curriculum, 31(1), 94-110.

Shamsi, A., Altaha, S., \& Gilanlioglu, I. (2019). International Journal of Linguistics , Literature and Translation ( IJLLT ) ISSN : 2617-0299 The Role of M-Learning in Decreasing Speaking Anxiety for EFL Learners.

Souriyavongsa, T., Rany, S., Jafre Zainol Abidin, M., \& Lai Mei, L. (2013). Factors Causes Students Low English Language Learning: A Case Study in the National University of Laos. International Journal of English Language Education, 1(1), 179-192. https://doi.org/10.5296/ijele.v1i1.3100

Studies, L., International, A., \& Centre, A. (2016). Investigating the Perceptions of Pakistani English Language Learners on Language Learning Anxiety in EFL Classroom. Advances in Language and Literary Studies, 7(5).

Sukitkanaporn, T., \& Phoocharoensil, S. (2014). English presentation skills of Thai graduate students. English Language Teaching, 7(3), 91-102. 
Pratika Ayuningtyas, Tell : Teaching of English Language and Literature

Vol. 8, No. 1, 7 - 18 Doi: http://dx.doi.org/10.30651/tell.v8i1.4327

Tian, C. (2019). Anxiety in Classroom English Presentations: A Case Study in Korean Tertiary Educational Context. Higher Education Studies, 9(1), 132.

Toland, S., Mills, D., \& Kohyama, M. (2016). Enhancing japanese university students' englishlanguage presentation skills with mobile-video recordings. JALT CALL Journal, 12(3), 179-201.

Tridinanti, G. (2018). The Correlation between Speaking Anxiety, Self-Confidence, and Speaking Achievement of Undergraduate EFL Students of Private University in Palembang. International Journal of Education and Literacy Studies, 6(4), 35.

van Ginkel, S., Gulikers, J., Biemans, H., \& Mulder, M. (2017). Fostering oral presentation performance: does the quality of feedback differ when provided by the teacher, peers or peers guided by tutor? Assessment and Evaluation in Higher Education, 42(6), 953-966.

Vo, T., Samoilova, V., \& Wilang, J. (2017). The International Conference of Innovation in Education (ICIE). Debilitating Effects of Anxiety on Engineering Students Language Performances, 12.

Yassin, A., \& Razak, N. (2018). Investigating Foreign Language Learning Anxiety Among Yemeni University EFL Learners: A Theoretical Framework Development. English Language Teaching, 11(10), 38 . 
Pratika Ayuningtyas, Tell : Teaching of English Language and Literature

Vol. 8, No. 1, 7 - 18 Doi: http://dx.doi.org/10.30651/tell.v8i1.4327

\section{Appendix:}

The Foreign Language Classroom Anxiety Scale (FLCAS)

\begin{tabular}{|l|l|l|l|}
\hline 1 Strongly Disagree & 2 Disagree & 3 Agree & 4 Strongly Agree \\
\hline
\end{tabular}

\begin{tabular}{|c|c|c|c|c|c|}
\hline Q1 & I never feel quite sure of myself when I am speaking in the English class. & 1 & 2 & 3 & 4 \\
\hline Q2 & I don't worry about making mistakes in the English class & 1 & 2 & 3 & 4 \\
\hline Q3 & I tremble when I know that I'm going to be called on in the English class. & 1 & 2 & 3 & 4 \\
\hline Q4 & $\begin{array}{l}\text { It frightens me when I don't understand what the teacher is saying in the English } \\
\text { class. }\end{array}$ & 1 & 2 & 3 & 4 \\
\hline Q5 & $\begin{array}{l}\text { During English class, I find myself thinking about things that have nothing to do } \\
\text { with the course. }\end{array}$ & 1 & 2 & 3 & 4 \\
\hline Q6 & I keep thinking that the other students are better at languages than I am. & 1 & 2 & 3 & 4 \\
\hline Q7 & I am usually at ease during tests in my English class. & 1 & 2 & 3 & 4 \\
\hline Q8 & I start to panic when I have to speak without preparation in the English class. & 1 & 2 & 3 & 4 \\
\hline Q9 & I worry about the consequences of failing my English class. & 1 & 2 & 3 & 4 \\
\hline Q10 & I don't understand why some people get so upset over foreign lar & 1 & 2 & 3 & 4 \\
\hline Q11 & In English class, I can get so nervous I forget things I know. & 1 & 2 & 3 & 4 \\
\hline Q12 & It embarrasses me to volunteer answers in my English class. & 1 & 2 & 3 & 4 \\
\hline Q13 & I would not be nervous speaking English with native speakers. & 1 & 2 & 3 & 4 \\
\hline Q14 & I get upset when I don't understand what the teacher is correcting. & 1 & 2 & 3 & 4 \\
\hline Q15 & Even if I am well prepared for the English class, I feel anxious about it & 1 & 2 & 3 & 4 \\
\hline Q16 & I often feel like not going to my English class. & 1 & 2 & 3 & 4 \\
\hline Q17 & I am afraid that my language teacher is ready to correct every mistake I make. & 1 & 2 & 3 & 4 \\
\hline Q18 & I feel confident when I speak in the English class. & 1 & 2 & 3 & 4 \\
\hline Q19 & I can feel my heart pounding when I'm going to be called on in class. & 1 & 2 & 3 & 4 \\
\hline Q20 & The more I study for a English test, the more confused I get. & 1 & 2 & 3 & 4 \\
\hline Q21 & I don't feel pressure to prepare very well for the English class. & 1 & 2 & 3 & 4 \\
\hline Q22 & I always feel that the other students speak English better than I do. & 1 & 2 & 3 & 4 \\
\hline Q23 & I feel very self-conscious about speaking English in front of other students. & 1 & 2 & 3 & 4 \\
\hline Q24 & Language class moves so quickly I worry about getting behind. & 1 & 2 & 3 & 4 \\
\hline Q25 & I feel more tense and nervous in my English class than in any other class. & 1 & 2 & 3 & 4 \\
\hline Q26 & I get nervous when I am speaking in my English class. & 1 & 2 & 3 & 4 \\
\hline Q27 & When I'm on my way to English class, I feel very sure and relaxed. & 1 & 2 & 3 & 4 \\
\hline Q28 & I get nervous when I don't understand every word of the language teacher & 1 & 2 & 3 & 4 \\
\hline Q29 & I feel overwhelmed by the number of rules one has to learn to speak English. & 1 & 2 & 3 & 4 \\
\hline Q30 & I am afraid that the other students will laugh at me when I speak English. & 1 & 2 & 3 & 4 \\
\hline Q31 & I would probably feel comfortable around native speakers of English. & 1 & 2 & 3 & 4 \\
\hline Q32 & I get nervous when the instructor asks questions that I haven't prepared. & 1 & 2 & 3 & 4 \\
\hline Q33 & It wouldn't bother me at all to take more English class & 1 & 2 & 3 & 4 \\
\hline
\end{tabular}

